sind die Haare schief. Kopf glanzlos, oben und unten längsgestreift; am Scheitel divergieren die Streifen und sind am Hinterkopf fast quer; Seiten hinter den Augen und Hinterecken glänzend, ungestreift; Thorax gröfstenteils gestreift. Petiolus gerunzelt; Scutellum, Epinotum, Mesopleure und obere Fläche des Postpetiolus glatt und glänzend, zerstreut punktiert. Kopf wenig länger als breit, vorn etwas schmäler; Mandibel breit, mit $6-7$ Zähnen; Stirnleisten kurz, voneinander weit entfernt; eine glatte Furche erstreckt sich vom vorderen Ocellus zum Vorderrand des Clypeus, wo er beiderseits durch einen stumpfen Winkel begrenzt ist. Thorax niedrig, enger als der Kopf; Epinotum mit stumpfen, platten Zähnen. Petiolus vorn zylindrisch, hinten mit querem Knoten; Postpetiolus wenig breiter, etwa so lang wie breit. L. $4,5 \mathrm{~mm}$. Flügel unbekannt.

Westmorea. - 9 und $\sigma^{\top}$ unbekannt.

\title{
A new genus and two new species of Foeninae from Sonoran California. (Hym.)
}

By J. Chester Bradley, Ithaca, N. Y.

(Hierzu Tafel I.)

In the Transactions of the Entomological Society of America, XXVII, p. 109, 1908, I indicated that Foenus sericeus Cameron belongs to the genus Pseudofoenus. It does agrees with that genus in wing venation, and I was familiar with only the published descriptions and figures. I have now a species from California, sent me by Mr. Baker, which is evidently congeneric with sericeus, but which differs in many important characters from the type of Pseudofoenus, $P$. pedunculatus. This confirms the suspicion that I had already entertained from the difference in distribution that in the American species we have really a distinct and undescribed genus. Pseudofoenus is known from New Zealand and New Guinea, and my new genus from Guatemala and California. It is improbable that there is any close genetic relation between the two, the similarity in wing venation having in all likelihood arisen independently in both. In fact it is very possible that Psendofoenus may have derived its venation directly from the condition found in Hyptiogaster, by the loss of the longitudinal sector of the free part of $\mathrm{M}_{1}$ instead of from the Foenus type of wing, by the loss of $\mathrm{M}_{4}$. There is not sufficient evidence at hand to decide the matter. 
The mandibles show a progressive series which correlates with that afforded by the wings. In Hyptiogaster we have the most primitive wing, and a very simple type of mandible; in Pseudofoenus appears a small recurved tooth at base which becomes enormously developed in Foenus at the same time that the mandibles become short and thick, while in Rhydinofoenus this tooth is by far the largest part of the mandible, and the apex itself remains as only little spurs, without notches or teeth beneath.

Eufoenus Szepligeti is a synonym of Hyptiogaster, its type being fixed by inclusion as $H$. antennalis. It was published the same year, 1903, but a little later in the year than Hyptiogaster.

\section{Table to the genera of Foninae.}

A. Cell $\mathrm{M}_{4}$ in the front wings in its normal position, its caudal border on a line with $\mathrm{Cu}$ and $\mathrm{Cu}_{1}$; mandibles without a recurved tooth at base; femora and tibiae sometimes much swollen but not clavate; claw very large; head and neck not elongate.

Hyptiogaster Kieffer.

(Type Gasteruption antennale Schletterer.)

AA. Cell $\mathrm{M}_{4}$ in the front wings crowded caudad, so that its cephalic border is in line with $\mathrm{Cu}$ and $\mathrm{Cu}_{1}$, or fused with $\mathrm{M}_{3}$ (or perhaps $\mathrm{R}$ ); mandibles with recurved tooth at base; posterior tibiae swollen and clavate.

B. Mandibles long, a comparatively small recurved tooth near the base and irregular teeth between it and the apex; tarsal segments long, the metatarsus not exceeding the following three segments together; claw large; wings with the cell $\mathrm{M}_{4}$ fused with $\mathrm{M}_{3}$ (or perhaps with $\mathrm{R}$ ); abdomen scarcely petiolate, but little compressed. Pseudofoenus Kieffer.

(Type Gasteruption pedunculatum Schletterer.)

BB. Mandibles short and stout, bearing a very large recurved tooth within, and with or without a notch between this and the apex; tarsal segments short; the metatarsus considerably exceeding the following three segments united; claws minute.

C. Front wings with the cell $\mathrm{M}_{3}$ and $\mathrm{M}_{4}$ separated; mandibles with a notch within near the apex.

Foenus Fabr.

(Type Ichneumon assectator Linnaeus.)

CC. Front wings with the cells $\mathrm{M}_{3}$ and $\mathrm{M}_{4}$ fused; mandibles without a notch within before the apex.

Rhydinofoenus n. gen.

(Type Rhydinofoenus kaveahensis n. sp.) 
Rhydinofoenus n. gen.

Fore wings less than twice as long as the petiole, shorter than the ovipositor; mesonotum not striate.

kaweahensis n. sp.

Fore wings considerable more than twice as long as the petiole, longer than the ovipositor; mesonotum strongly transversestriate.

sericeus Cameron.

\section{Rhydinofoenus kaweahensis n. sp.}

․ Black, shading into brown especially on the legs; propleurae, meso- and metapleurae below, propodeum, mesaventer, posterior coxae beneath, extreme apex of first four abdominal segments, and terebra, red; anterior and middle legs with the second segment of the trochanters, knees, tibiae at apex and base of tarsi white; posterior legs with the second segment of the trochanters and rings near base of tibiae white; mandibles pale with dark tips; sheaths of ovipositor tipped with white.

Habitus very compressed and slender. Face from in front long obovate; inner margins of the compound eyes converging below; eyes reaching the mandibles; face and forehead white tomentose; vertex much prolonged behind the eyes, impunctate, opaque; anterior ocellus slightly behind a line connecting the posterior margins of the compound eyes; antennae fourteensegmented, short, about equal in length to the petiole, the first three and one-half segments nearly glabrous, the remaining pubescent; basal four segments in the proportions of about 7-7-10-9. Neck long, very minutely shagreened. Mesonotum shagreened and with scattered punctures, so shallow as to be scarcely evident; anterior grooves short, not very distinct; parapsidal grooves marked with a line of deep punctures; propleurae with a short sharp tooth on the anterior margin; almost imperceptably shagreened, with a few coarse wrinkles in the centre; mesopleurae a little rougher, with a tendency to reticulation around the edges; scutellum minutely shagreened, bordered on each side by a carina; propodeum reticulate. Wings short, less than twice as long as the petiole, hyaline; posterior coxae minutely punctate. Abdomen opaque.

Length $9 \mathrm{~mm}$; fore-wing $4 \mathrm{~mm}$; ovipositor $5 \mathrm{~mm}$.

Described from one female from Three Rivers, Tulare Co., Cal., on the Kaweah River in the foothills of the Sierras, collected by Mr. Culbertson, and studied by courtesy of $\mathrm{Mr}$. C. F. B a ker. 
Foenus visaliae $\mathrm{n}$. $\mathrm{sp}$.

9. Black; anterior coxae, trochanters, and femora brownish yellow; the tibiae and tarsi white, the former with a brown line within ; middle coxae, trochanters and femora brownish yellow, the tibiae and tarsi fuscous, a white line on the former without, and the basal two-thirds of metatarsus white; second segment of posterior trochanters brownish yellow, a ring near base of tibiae, and a wider ring near base of tarsi, white; first two abdominal segments tipped with rufous laterally; sheaths of ovipositor white at apex.

Habitus long and slender. Face, pleurae, etc. slightly silvery tomentose. Head oval, moderately prolonged behind the eyes; inner margin of these converging anteriorly, reaching the mandibles; posterior ocelli placed on a line connecting the posterior margin of the compound eyes, slightly nearer the compound eyes than to each other; vertex opaque; antennae as long as the petiole plus $2 / 3$ of the second dorsal segment; first four segments in the proportions of approximately $7-5-8-12$. Neck elongate, minutely transversely wrinkled. Medial mesothoracic lobe minutely confluently pitted, with many scattered coarser punctures; the anterior grooves distinct, parapsidal grooves marked with a line of reticulate punctures; behind the parapsidal grooves the mesonotum mesally is coarsely reticulate-punctured; humeral angles with a sharp tooth; scutellum minutely confluently pitted with a few scattered coarser punctures, and a row of coarse reticulate punctures along the sides; propodeum mesally with coarse round reticulate punctures, laterally reticulate; posterior coxae minutely transversely wrinkled; wings twice as long as the petiole. Abdomen long and slender with a dull lustre.

Length $11 \mathrm{~mm}$; fore-wing $5 \mathrm{~mm}$; petiole $2,5 \mathrm{~mm}$; abdomen $8 \mathrm{~mm}$; ovipositor $9 \mathrm{~mm}$.

A second specimen has spot on third abdominal segment and base of posterior coxae reddish.

Claremont, in eastern Los Angeles Co., Cal., 1 q, type collected by Mr. C. F. Baker; Visalia in Tulare Co., Cal., 1 q, Mr. Culbertson. Both of these are strictly Sonoran localities. Specimens studied by courtesy of Mr. C. F. Baker.

\section{Explanation of Plates.}

Fig. 1. Forewing of Hyptiogaster crassiceps Schlett., + , X 18, veins labelled.

"2. Wings of Pseudofoemus pedunculatus Schlett., + , X 18.

"3. Forewing of Foenus visaliae n. sp., + , X 36, cells labelled. 
Fig. 4. Wings of Rhydinofoenus kaveahensis, ㅇ, X 36 .

5. Right mandible of Hyptiogaster humeralis Schlett., $q$, as seen from above.

" 6. Right mandible of Pseudofoenus pedunculatus Schlett., o7, as seen from above.

7. Right mandible of Foenus incertus Cresson, as seen from above.

8. Right mandible of Rhydinofoenus kaweahensis n. sp., 우, as seen from above.

Figs. 5 to 8 are of the same degree of magnification.

\section{Zar Kenntnis einiger paläarktischer Bienen und Beschreibung zweier neuer Arten. (Hym.)}

Von J. D. Altken, Bremen.

Andrena nigrospina Thoms.

Diese Art ist ohne Zweifel eine ausgeprägte Färbung der A. carbonaria L. (pilipes F.), bei der der Thorax und die Hinterleibsbasis weifsgrau gefärbt sind. Solche Farbenvarietäten sind bei Bremen nicht selten und treten in beiden Geschlechtern, besonders in der zweiten Generation, seltener in der Frühjahrsform auf. Die ovale Grube seitlich an der Basis des zweiten Hinterleibsringes finde ich bei dieser Varietät ebenfalls, wenn auch viel weniger deutlich als bei der Stammform entwickelt. Bei manchen Exemplaren ist sie nur bei starker Vergröfserung zu erkennen, so dafs man wohl verstehen kann, dafs Thom son sie als fehlend bezeichnet. S $\mathrm{chmi}$ edeknecht hat die $A$. nigrospina in seinen "Apidae Europaeae" mit A. Flessae Pz. zusammen hinter A. cineraria L. gestellt. Wegen des grob gerunzelten Mittelfeldes des Mittelsegments hat sie aber neben A. carbonaria L. zu stehen. Alle Arten mit einer so scharf gefurchten Area des Mittelsegments sind meiner Meinung nach zu einer Gruppe, die A. carbonariaGruppe heifsen kann, zu vereinigen. Dahin gehören auch $A$. albicans Müll., Flessae Pz., tibialis K., bimaculata K. und asperrima Pér. Zu A. bimaculata $\mathrm{K}$. ist $A$. Morawitzi Thoms. als rotbeinige Rasse und A. decorata Smith (= Magrettiana Schmied.) als Varietät mit teilweise rot gefärbtem Hinterleib zu rechnen. A. nigrospina Thoms., hat übrigens einen schwach blauschimmernden Hinterleib, Thom son nennt ihn "vix coeruleo micante"; Schmiedeknecht durfte die Art in seiner Tabelle daher nicht unter den Arten mit schwarzem Hinterleib aufführen. (Kennziffern 33 und 47, Seite 442.) 


\section{$2 \mathrm{BHL}$ Biodiversity Heritage Library}

Bradley, J. Chester. 1909. "A new genus and two new species offoeninae from Sonoran California. (Hym.)." Deutsche entomologische Zeitschrift 1909(1), 37-41. https://doi.org/10.1002/mmnd.48019090106.

View This Item Online: https://www.biodiversitylibrary.org/item/103377

DOI: https://doi.org/10.1002/mmnd.48019090106

Permalink: https://www.biodiversitylibrary.org/partpdf/235931

\section{Holding Institution}

Harvard University, Museum of Comparative Zoology, Ernst Mayr Library

\section{Sponsored by}

Biodiversity Heritage Library

\section{Copyright \& Reuse}

Copyright Status: Public domain. The BHL considers that this work is no longer under copyright protection.

This document was created from content at the Biodiversity Heritage Library, the world's largest open access digital library for biodiversity literature and archives. Visit BHL at https://www.biodiversitylibrary.org. 